\title{
ANALISIS PERMINTAAN SOUVENIR DI PASAR SENI UBUD GIANYAR, BALI
}

\author{
Diah Tantri Meilani ${ }^{1}$, I Made Kusuma Negara ${ }^{2}$, Luh Gede Leli Kusuma Dewi ${ }^{3}$ \\ ${ }^{1}$ Email: meilanidiah@yahoo.co.id \\ Program Studi S1 Industri Perjalanan Wisata, Fakultas Pariwisata, Universitas Udayana \\ ${ }^{2}$ Email: kusuma.negara@unud.ac.id \\ Program Studi S1 Industri Perjalanan Wisata, Fakultas Pariwisata, Universitas Udayana \\ ${ }^{3}$ Email: leli.kusumadewi@gmail.com \\ Program Studi S1 Industri Perjalanan Wisata, Fakultas Pariwisata, Universitas Udayana
}

\begin{abstract}
The globalization era has changed the economic order of society such as the demand decrease of souvenirs in traditional markets because the increasing number of modern market, especially in Bali. The aim of this research is to find out variables that influence the demand of souvenirs in traditional market and hopefully can be used as a benchmark in maintaining the existence of traditional art market, increasing the demand of souvenirs, income, and increasing the number of tourist visits to Ubud traditional market, Gianyar Bali. The respondent in this study include visitors and tourists of Ubud art market. Determination of the sample in this study using purposive sampling method as much as 130 respondents. Technical data using questionnaires and interviews. This research use data analysis technique such as; of validity and reliability test, classical clinical test, determination test, multiple linear regression analysis and hypothesis test. Partially, the results showed if motivation on buying souvenir with influence equal 18,955 (2) perceived value of souvenir with influence equal 3,525, (3) consumer behavior with influence equal 20,212. Meanwhile, simultaneously showing motivation to buy souvenirs, perceived value of souvenir and consumer behavior shows the total influence 419,961. From the result of quantitative descriptive analysis, known that the most influence variables of demand analysis in Ubud art market is consumer behavior which consist of market location, cleanliness, price, parking area, infrastructure, and market hours (opening - closed hours).
\end{abstract}

Abstrak: Era globalisasi telah mengubah tatanan perekonomian masyarakat seperti menurunnya jumlah permintaan souvenir di pasar tradisional karena semakin banyaknya pasar modern yang menjual oleh-oleh khususnya di Bali. Tujuan dari penelitian ini yaitu untuk mengetahui variabel yang berpengaruh terhadap permintaan barang yang ada di pasar tradisional dan diharapkan dapat digunakan sebagai tolak ukur dalam menjaga eksistensi pasar seni tradisional, meningkatkan permintaan barang dan pendapatan para pedagang, serta meningkatkan jumlah kunjungan wisatawan ke pasar seni pasar seni Ubud Gianyar Bali. Responden yang menjadi sampel dalam penelitian ini meliputi wisatawan atau pengunjung di pasar seni Ubud. Penentuan sampel dalam penelitian ini menggunakan metode accidental sampling sebanyak 130 responden. Teknik pengumpulan data menggunakan kuesioner dan wawancara. Teknik analisis data dalam penelitian ini adalah uji validitas dan realibilitas, uji asumsi klasik, uji determinasi, analisis regresi linear berganda dan uji hipotesis . Hasil penelitian menunjukkan bahwa secara parsial, variabel-variabel yang berpengaruh dalam penelitian analisis permintaan souvenir dengan hasil sebagai berikut: (1) motivation on buying souvenir dengan pengaruh sebesar 18,955 (2) perceived value of souvenir dengan pengaruh sebesar 3,525 , (3) consumer behavior dengan pengaruh sebesar 20,212. Sementara itu secara simultan menunjukkan bahwa pengaruh variabel motivation on buying souvenir, perceived value of souvenir dan consumer behavior terhadap jumlah permintaan souvenir terdapat pengaruh sebesar 419,961. Dari hasil analisis deskriptif kuantitatif dapat diketahui bahwa variabel yang paling berpengaruh terhadap jumlah permintaan souvenir di pasar seni Ubud yaitu consumer behavior yang terdiri dari lokasi pasar, kebersihan pasar, harga, tempat parkir, infrastruktur dan jam operasional pasar.

Keywords: traditional market; motivation on buying souvenir; perceived value of souvenir; consumer behavior; demand analysis. 


\section{PENDAHULUAN}

Bali sebagai salah satu pulau yang seiring dengan peningkatan kunjungan wisatawan ke Bali perlu dikembangkan beberapa fasilitas yang mampu mempermudah dan memenuhi kebutuhan wisatawan saat berkunjung. Mengacu Hasil Survei Perilaku Wisatawan Mancanegara (Superwisman) yang dilakukan Kantor Perwakilan Bank Indonesia Bali, pengeluaran wisatawan mancanegara pada periode tahun 2015 adalah untuk akomodasi sebesar 26,69 makan dan minum 18,53\% dan belanja sebesar $14,80 \%$ dan diikuti oleh komposisi pengeluaran lainnya seperti sightseeing dan sebagainya (Bali Bisnis:2015)

Wisatawan datang ke Bali selain menikmati keindahan alam juga melakukan kegiatan berbelanja sebagai oleh-oleh. Menurut Pandit (2002) menyebutkan selama melakukan perjalanan, uang yang digunakan salah satunya dicatat untuk keperluan membeli souvenir.

Untuk mengimbangi pola konsumsi wisatawan terhadap kegiatan berwisata seperti pembelian souvenir, pemerintah mendorong masyarakat untuk mengembangkan usaha kecil dan menengah atau yang dikenal dengan UKM dan membangun beberapa pasar traditional yang khusus menjual beberapa souvenir atau oleh-oleh khas Bali. Sektor perdagangan industri kecil dan kerajinan dewasa ini terkonsentrasi pada pasar seni tradisional (Federico, 2006).

Gianyar sebagai salah satu kabupaten yang memiliki kemajuan di sektor pariwisata, perdagangan dan industri pengolahan sangat tinggi dan memiliki prospek yang baik untuk jangka panjang. Saat ini Kabupaten Gianyar telah mengelola beberapa pasar seni tradisional dan dikelola oleh masing-masing Desa Adat.

Namun pasar seni tradisional yang dulunya selalu ramai dikunjungi wisatawan, mulai mengalami penurunan dengan hadirnya pasar seni modern sehingga berdampak signifikan terhadap penghasilan pedagang lokal dalam kesehariannya. Menurut Purnama dan Yasa (2013), perkembangan pasar oleh-oleh modern sangat meresahkan pedagang di pasar tradisional, karena dikhawatirkan akan mematikan pasar oleh-oleh tradisional. Selain komoditi yang sama, harga yang ditawarkan oleh pasar seni modern tidak kalah bersaing dengan pasar seni tradisional

Menurut data Badan Pelayanan dan Perijinan Terpadu Kabupaten Gianyar, terdapat lebih dari 10 (sepuluh) pasar oleh-oleh modern di Kabupaten Gianyar saat ini. Lokasi pasar oleh-oleh modern ini sangat strategis yaitu di sepanjang jalan raya Batubulan - Celuk hingga di kota (Cahyadi Putra, 2012). Kondisi ini sangat meresahkan pedagang di pasar seni tradisional yang terdapat di Kabupaten Gianyar. Kondisi tersebut mempengaruhi demand and supply souvenir yang ada di pasar tradisional.

Oleh karena itu perlu adanya analisis kesenjangan yang terjadi di pasar seni tradisional dan variabel apa saja yang mempengaruhi permintaan akan souvenir di Pasar Seni Ubud sehingga hal tersebut dapat digunakan sebagai tolak ukur dalam menjaga eksistensi pasar seni tradisional. Adapun tujuan dari penelitian ini, yaitu untuk mengetahui pengaruh motivation on buying souvenir, perceived value of souvenir, dan consumer behavior terhadap permintaan souvenir di pasar seni Ubud Gianyar secara parsial dan untuk mengetahui pengaruh motivation on buying souvenir, perceived value of souvenir, dan consumer behavior terhadap permintaan souvenir di pasar seni Ubud Gianyar secara simultan.

\section{METODE}

Adapun variabel yang digunakan dalam analisis permintaan souvenir dikaitkan dengan teori konsumen (cardinal dan ordinal) dan teori konsumen (teori ekonomi mikro, antropologis dan psikologis). Variable tersebut diantaranya motivasi untuk membeli souvenir (X1), termaksud peran souvenir sebagai hadiah, (Kim and Littrell 2001; Gordon 1986), sebagai tanda (Gordon 1986), dan sebagai pengingat (Littrell et al. 1994; Swanson 2004). Peran souvenir sebagai hadiah meliputi peran reintegrasi dan desakralisasi (Gordon 1986) serta perilaku pemberian hadiah dan self-gifting. Kemudian, perceived value of souvenir nilai tukar dari souvenir (X2), dapat didefinisikan kaitannya dengan komoditas lain sebagai nilai obyektif dari semua komoditas (Shepherd, 2002). Indikator perceived value of souvenir yang digunakan oleh (F. Vasheghani-Farahani; 2014 adalah; model/design, motif, dan quality 3. Consumer Behavior (X3) perilaku konsumen mengikutkan pikiran dan perasaan yang dialami manusia dan aksi yang dilakukan saat proses konsumsi (Peter \& Olson, 2005) Adapun indikator pola perilaku konsumen yang dimaksud yaitu; lokasi pasar, kebersihna, 
harga, infrastruktur, fasilitas parker, dan jam operasional.

Teknik pengumpulan data yang digunakan yaitu; wawancara, kuesioner, observasi, serta studi kepustakaan. Teknik penentuan informan ditentukan secara purposive sampling, observasi dan wawancara kepada orang-orang yang dipandang tahu tentang situasi sosial tersebut.

Penentuan sampel dilakukan dengan accidental sampling, siapa saja yang secara kebetulan dapat dijadikan sebagai sampel dan cocok sebagai sumber data (Sugiyono 2014: 85). Jumlah responden yang digunakan ialah sebanyak 130 responden yang terbagi kedalam wisatawan mancanegara dan domestik. Teknik analisis data menggunakan analisis kualitatif dan analisis kuantitatif regresi berganda.

\section{HASII}

\section{Gambaran Umum Pasar Seni Ubud Gianyar}

Pasar Ubud atau yang lebih dikenal sebagai Pasar Seni Ubud merupakan pasar tradisional yang memiliki lokasi strategis bagi wisatawan atau pengunjung yaitu di pusat jantung pariwisata Ubud. Banyak wisatawan yang berkunjung ke pasar seni Ubud karena lokasinya yang berdekatan dengan beberapa objek wisata bersejarah di daerah Ubud dan lokasinya yang mudah diakses bagi wisatawan.

Pasar seni Ubud merupakan pusat ekonomi masyarakat disekitarmya. Pasar ini dibagi menjadi dua bagian dengan barang dagangan yang berbeda bila dilihat dari barat ke timur. Di bagian barat pasar seni Ubud merupakan pasar seni tradisional yang menjual souvenir khas Bali, sedangkan pada blok timur merupakan pasar yang menjual kebutuhan pasar mendasar tradisional sehari-hari atau sembako. Normalnya pasar seni Ubud akan mulai beroperasi pukul 08.00 pagi hingga 6 sore, sedangkan untuk pasar yang menjual kebutuhan sehari-hari akan mulai beroperasi pada pukul 4 pagi hingga siang hari.

Pasar seni Ubud pernah mengalami musibah kebakaran dari yang kecil hingga kebakaran besar yang menghanguskan bagian barat pasar pada tahun 2016, sehingga tidak sedikit pedagang pasar seni Ubud yang bergulung tikar atau memilih untuk direlokasi ke bagian timur pasar. Relokasi pasar tersebut tentunya mengakibatkan lahan parkir yang menyempit dan tentunya membatasi ruang gerak pengunjung atau pedagang di pasar Ubud.
Pasar seni Ubud menawarkan berbagai macam souvenir atau kerajinan yang lengkap dan banyak digemari oleh wisatawan sebagai tempat wisata belanja, Harga yang ditawarkan mulai dari sepuluh ribuan hingga jutaan rupiah. Berbagai macam souvenir atau pernak-pernik bisa ditemukan seperti kain bali, gantungan kunci, magnet, berbagai anyaman, lukisan dan lain sebagainya. Selain itu harga yang ditawarkan oleh pedagang cukup terjangkau karena barang yang dijual oleh mereka diambil langsung dari pengrajinnya.

Pihak desa adat Ubud menyediakan shuttle service bagi pengunjung pasar. Shuttle tersebut diperuntukkan bagi wisatawan group yang mengalami kesusahan aksesbilitas menuju pasar karena sistem satu arah dan untuk meminimalisir kemacetan di daerah Ubud. Untuk shuttle service wisatawan akan dikenakan biaya Rp 50.000 . Lahan parkir yang sempit di pasar Ubud juga menjadi permalasahan bagi pengunjung dan pihak pasar sehingga dengan adanya shuttle service akan memudahkan wisatawan untuk berkunjung ke pasar seni Ubud. Pasar seni Ubud merupakan salah satu pasar seni tradisional di Bali yang masih bertahan di era persaingan pasar-pasar modern lainnya. Sampai saat ini, jumlah pedagang di Pasar Seni Ubud berdasarkan tahun 2016 jumlahnya masih mencapai 1.099 pedagang. Jumlah tersebut dibagi menjadi pedagang yang aktif dan tidak aktif. Sebanyak 822 pedagang yang masih aktif dan 277 pedagang yang tidak aktif

\section{Karakteristik Pengunjung Pasar Seni Ubud Gianyar}

Dari 130 responden dalam penelitian ini dibagi menjadi dua yaitu wisatawan mancanegara dan wisatawan domestik. Mayoritas pengunjung pasar seni Ubud yaitu wisatawan mancanegara wanita yang mencapai jumlah 67 orang berbanding dengan wisatawan domestik wanita sejumlah 15 orang atau dengan presentase sebesar $51 \%$ dan $11,5 \%$. Karakteristik variabel asal wilayah atau benua yang mendominasi yaitu wisatawan mancanegara asal wilayah atau benua Eropa dengan presentase mencapai 37\%. Dapat juga dilihat bahwa dari beberapa klasifikasi usia, pengunjung 15-24 tahun yang mendominasi kunjungan di pasar seni Ubud dengan presentase sebesar $40 \%$ atau sebanyak 52 responden wisatawan mancanegara dan 15 responden $(11,5 \%)$ merupakan wisatawan domestik. 
Karakteristik lainnya yang berpengaruh terhadap jumlah permintaan souvenir di pasar Ubud yaitu pengeluaran wisatawan atau pengunjung dalam berbelanja souvenir didominasi oleh rata-rata pengeluaran USD 15 - 37 untuk wisatawan mancanegara dan pengeluaran souvenir sebesar Rp 400.000 - Rp 800.000 untuk wisatawan domestik dengan presentase $40,7 \%$ dan $10 \%$. Tujuan utama pengunjung atau wisatawan ke pasar seni Ubud yaitu untuk berbelanja souvenir dengan presentase sebesar $50,7 \%$ atau sebanyak 66 responden untuk wisatawan mancangera, diikuti oleh wisatawan domestik sebesar 15,3\% (20 orang) dengan tujuan ingin berbelanja souvenir.

Selanjutnya adalah motivasi pengunjung atau wisatawan berbelanja souvenir di pasar seni Ubud sebagai hadiah atau "souvenir as gift" dengan presentase sebesar 53,8\% atau sebanyak 70 wisatawan mancanegara dan diikuti oleh presentase pengunjung atau wisatawan domestik sebesar 13,8\% (18 orang) Jenis souvenir yang sering dipilih oleh pengunjung atau wisatawan ketika mereka berbelanja ke pasar seni Ubud yaitu jenis "Local craft" atau kerajinan lokal seperti hasil anyaman, Balinese accessories, kain bali, hasil kerajinan ukir atau ornament dan sebagainya dengan presentase sebesar $43,8 \%$ atau sebanyak 57 pengunjung dan wisatawan mancanegara, lalu diikuti oleh wisatawan domestik dengan presentase $23 \%$ atau sebanyak 30 orang yang menjawab demikian.

\section{HASIL}

Uji validitas dalam penelitian ini digunakan untuk mengukur valid atau tidaknya butir instrument atau indikator yang digunakan dalam kuesioner. Hal tersebut penting dilakukan karena berkaitan dengan keakuratan sebuah data. Uji validitas dalam penelitian ini dikatakan valid apabila koefisien korelasi sama dengan 0,3 atau lebih (paling kecil 0,3). Berdasarkan hasil uji validitas dapat dinyatakan bahwa semua indikator yang telah diuji adalah valid, hal tersebut terjadi karena nilai dari masing-masing indikator mempunyai nilai korelasi lebih dari 0,3 (Ghozali, 2005). Instrumen tertinggi dalam penelitian yang diuji yaitu variabel Consumer behavior $\left(\mathrm{X}_{3}\right)$ dengan koefisien korelasi 0,996 atau indikator jam operasional atau buka - tutup pasar seni Ubud Bali. Sedangkan instrumen tertinggi dari variabel Perceived value of souvenir $\mathrm{X}_{2} .1$ dengan koefisien korelasi 0,911 atau indikator model atau design souvenir di pasar seni Ubud menarik dan instrumen tertinggi dari variabel Motivation on buying sovenir adalah $\mathrm{X}_{1} .5$ dengan koefisien korelasi sebesar 0,836 atau indikator motivasi membeli souvenir sebagai represent atau benda yang bisa mewakilkan daerah yang mereka kunjungi

Untuk pengukuran atau uji reliabilitas dalam penelitian ini dilakukan dengan pengukuran sekali saja atau one shoot. Pengukuran reliabilitas tersebut akan dibandingkan dengan pertanyaan lain atau mengukur reliabilitas dengan uji statistik Cronbach Alpha (a). Apabila nilai Cronbach Alpha (a) > 0,6 maka variabel yang diuji reliable. Dari hasil uji reliabilitas dapat disimpulkan bahwa pada pengujian reliabilitas dengan total 130 responden diperoleh nilai alpha cronbach 0,935 artinya hasil tersebut telah memenuhi syarat reliabel yaitu > 0,6

Uji Asumsi Klasik pada penelitian ini menggunakan tiga cara uji yaitu; uji Normalitas Kolmogrov Smirnof, Uji Multikolinearitas, dan Uji Heteroskedastisitas. Untuk menguji apakah data-data yang dikumpulkan berdistribusi normal atau tidak dapat dilakukan dengan metode uji statistik sederhana menggunakan uji normalitas Kolmogorov Smirnov. Metode pengujian normal tidaknya distribusi data dilakukan dengan melihat nilai signifikansi dari variabel. Apabila nilai signifikan lebih besar dari $\alpha=5 \%$ maka menunjukkan distribusi data tersebut normal. Berdasarkan hasil uji normalitas dengan model Kolmogrov Smirnov menunjukkan bahwa hasil uji normalitas menunjukkan nilai signifikansi yaitu $(0,110)$ yang artinya lebih besar daripada 0,05, maka dapat dikatakan bahwa data tersebut berdistribusi normal.

Uji multikolonieritas dalam penelitian bertujuan untuk menguji apakah terdapat korelasi antar variabel independen. Dikatakan terdapat problem multikolonieritas jika terjadi korelasi. Suatu model regresi yang baik seharusnya tidak terjadi korelasi diantara variabel independen. Pengujian ada atau tidaknya gejala multikolonieritas dilakukan dengan memperhatikan nilai matriks korelasi yang dihasilkan pada saat pengolahan data serta nilai VIF (Variance Inflation Faktor) dan Tolerance value. Terdapat dua kemungkinan pengambilan nilai keputusan berdasarkan VIF (Variance Inflation Faktor) dan Tolerance value apabila nilai tolerance lebih besar dari 0,10 maka tidak terjadi multikoliearisme Kemudian apabila nilai nilai VIF lebih kecil 
dari 10,00 maka tidak terjadi multikolinearitas. Dari hasil uji multikolonieritas dapat dilihat bahwa Tolerance value keseluruhan variabel independent lebih besar dari 0,10 dan nilai VIF (Variance Inflation Faktor) menunjukkan nilai lebih kecil dari 10,00 sehingga dapat disimpulkan bahwa keseluruhan variabel yang diuji tidak terjadi multikolinearitas.

Uji heteroskedastisitas dalam penelitian ini bertujuan untuk menguji apakah regresi terdapat ketidaksamaan varians dari residual dari satu pengamatan satu ke pengamatan yang lain dalam sebuah model. Menguji heteroskedastisitas dengan model ZPRED dan residualnya SRESID merupakan salah satu cara untuk mendeteksi ada atau tidaknya heteroskedastisitas dalam penelitian ini. Berdasarkan scatter plot dapat dilihat bahwa pada grafik scatter plot antara SRESID dan ZPRED dimana sumbu $\mathrm{Y}$ adalah $\mathrm{Y}$ yang telah diprediksi, dan sumbu $\mathrm{X}$ adalah residual ( $\mathrm{Y}$ prediksi - $\mathrm{Y}$ sesungguhnya) yang telah disudentized. Dapat dilihat dari grafik scatter plot terlihat bahwa titik-titik menyebar secara acak serta tersebar baik diatas maupun dibawah angka nol pada sumbu Y maka dapat disimpulkan bahwa tidak terjadi heteroskedastisitas pada model regresi yang digunakan.

Berdasarkan hasil analisis berganda antara variabel independen independen $\left(\mathrm{X}_{1}\right.$, $\mathrm{X}_{2}, \ldots \mathrm{X}_{\mathrm{n}}$ ) atau (motivation on buying souvenir, perceived quality of souvenir, consumer behavior) dengan variabel dependen (Y) atau jumlah permintaan souvenir dapat diperoleh persamaan regresi berganda sebagai berikut $Y$ $=a+b_{1} x_{1}+b_{2} x_{2}+b_{3} x_{3} e$

Sehingga persamaan regresi berganda dalam penelitian ini yaitu

$\mathrm{Y}=-3,871+0,132+0,066+0,147$

Dimana:

$\mathrm{Y}=$ Jumlah permintaan souvenir

$A=$ konstanta

$\mathrm{X}_{1}=$ Motivation on Buying Souvenir

$\mathrm{X}_{2}=$ Perceived Quality

$\mathrm{X}_{3}=$ Consumer Behavior

Untuk pengujian hipotesis dalam penelitian ini menggunakan 2 cara yaitu secara parsial (Uji T) dan simultan (uji F). Berikut hasil pengujian hipotesis dengan nilai t-hitung dan nilai signifikansi:

\section{Hasil Uji Signifikan Regresi Berganda Secara Parsial (Uji t)}

Jika nilai t Hitung positif dengan taraf signifikansi $(0,001)<\alpha(0,05)$ maka variabel motivation on buying souvenir, perceived value of souvenir dan consumer behavior berpengaruh positif dan signifikan terhadap variabel kepuasan wisatawan. Jika nilai $t$ Hitung dengan taraf signifikansi $(0,001)>\alpha$ $(0,05)$ maka variabel motivation on buying souvenir, perceived value of souvenir dan consumer behavior tidak berpengaruh positif dan signifikan terhadap variabel kepuasan wisatawan

\section{Motivation on Buying Souvenir (X1) terhadap permintaan souvenir $(Y)$}

Berdasarkan hasil t-hitung, variabel $X 1$ motivation on buying souvenir yang terdiri dari 3 indikator adalah sebesar 18,955 dan bernilai positif dengan tingkat signifikansi sebesar 0,000. Karena nilai t Hitung positif dan nilai signifikansinya $0,000<0,05$ dapat disimpulkan bahwa variabel motivation on buying souvenir berpengaruh positif dan signifikan terhadap jumlah permintaan souvenir

\section{Perceived Value of Souvenir (X2) terhadap permintaan souvenir (Y)}

Berdasarkan hasil t-hitung dinyatakan bahwa nilai t Hitung pada variabel perceived value of souvenir adalah 3,525 dengan taraf signifikansi sebesar 0,001. Karena nilai $t$ Hitung positif dan taraf signifikani $0,001<0,05$ maka dapat disimpulkan bahwa variabel perceived value of souvenir berpengaruh positif dan signifikan terhadap jumlah permintaan souvenir

\section{Consumer Behavior (X3) terhadap permintaan souvenir $(\mathrm{Y})$}

Berdasarkan nilai $t$ Hitung dan signifikansi, variabel consumer behavior adalah 20,212 dengan taraf signifikansi sebesar 0,000. Karena nilai $\mathrm{t}$ Hitung positif dan taraf signifikani $0,000<0,05$ maka dapat disimpulkan bahwa variabel consumer behavior berpengaruh positif dan signifikan terhadap jumlah permintaan souvenir.

Dari hasil uji signifikan regresi berganda secara parsial (t-test) dapat diketahui jika variabel bebas motivation on buying souvenir $\left(\mathrm{X}_{1}\right)$ perceived value of souvenir $\left(\mathrm{X}_{2}\right)$ dan consumer behavior $\left(\mathrm{X}_{3}\right)$ terbukti berpengaruh positif dan signifikan terhadap variabel terikat 
yaitu permintaan souvenir (Y) di pasar seni Ubud Bali sehingga hipotesis pertama dan kedua dalam penelitian ini telah terjawab dan terbukti.

\section{Hasil Uji Signifikan Regresi Berganda Secara Simultan (Uji F)}

Uji $F$ dalam penelitian ini digunakan untuk mengetahui tingkat signifikansi pengaruh variabel-variabel independen secara bersamasama (simultan) terhadap variabel dependen (Ghozali, 2005;84). Penentuan uji F dalam penelitian ini terdiri dari 2 tahapan sebagai berikut, jika nilai f Hitung positif dengan taraf signifikansi $(0,001)<\alpha(0,05)$ maka variabel motivation on buying souvenir, perceived value of souvenir dan consumer behavior berpengaruh positif dan signifikan terhadap variabel kepuasan wisatawan. Dan jika nilai $F$ Hitung dengan taraf signifikansi $(0,001)>\alpha$ $(0,05)$ maka variabel motivation on buying souvenir, perceived value of souvenir dan consumer behavior tidak berpengaruh positif dan signifikan terhadap variabel kepuasan wisatawan. Dari hasil F-hitung dan nilai signifikansi, dapat dilihat bahwa nilai f-hitung $(419,961)$ dengan tingkat signifikan $0,000<$ 0,05 maka $\mathrm{H}_{0}$ ditolak dan $\mathrm{H}_{1}$ diterima, sehingga variabel motivation on buying souvenir, perceived value of souvenir dan consumer behavior secara simultan berpengaruh positif dan signifikan terhadap jumlah permintaan souvenir di pasar seni Ubud Bali. Dapat disimpulkan bahwa dari hasil uji signifikan regresi berganda secara (F-test) maka keseluruhan variabel bebas yaitu motivation on buying souvenir $\left(\mathrm{X}_{1}\right)$ perceived value of souvenir $\left(\mathrm{X}_{2}\right)$ dan consumer behavior $\left(\mathrm{X}_{3}\right)$ secara simutan berpengaruh positif dan signifikan terhadap variabel terikat yaitu permintaan souvenir (Y) di pasar seni Ubud Bali. Sehingga hipotesis keempat dalam penelitian ini telah terjawab dan terbukti.

\section{Koefisien Determinasi}

Koefisien determinasi pada regresi linear yaitu untuk mengetahui tingkat ketepatan paling baik dalam analisa regresi dimana hal yang ditunjukan oleh besarnya koefisien determinasi (R2) antara 0 (nol) dan I (satu). Apabila koefisien determinasi semakin mendekati satu, maka dapat dikatakan bahwa variabel independen berpengaruh terhadap variabel dependen, sebaliknya Koefisien determinasi $\left(\mathrm{R}^{2}\right)$ nol maka variabel independen sama sekali tidak berpengaruh terhadap variabel dependen. Variabel bebas dalam penelitian ini meliputi motivation on buying souvenir (X1), The perceived value of souvenir (X2), dan consumer behavior (X3) terhadap variabel (Y) yaitu permintaan souvenir yang dinyatakan dalam bentuk persentase. Hasil pengujian koefisien determinasi yang dapat dilihat dari nilai $\mathrm{R}$ square pada analisis regresi berganda.

Berdasarkan hasil koefisien determinasi dapat dijelaskan bahwa koefisien determinasi memiliki nilai $\mathrm{R}$ square $(0,909)$ sehingga koefisien determinasi dalam penelitian ini sebesar 90,9\% dan menunjukkan bahwa variabel bebas yang meliputi motivation on buying souvenir $\left(\mathrm{X}_{1}\right)$ dan perceived value of souvenir $\left(\mathrm{X}_{2}\right)$ dan consumer behavior $\left(\mathrm{X}_{3}\right)$ terhadap variabel terikat yaitu permintaan souvenir (Y) sebesar 90,0\% sedangkan sisanya $100 \%-90,9 \%=9,1 \%$ dapat dipengaruhi oleh variabel-variabel lain diluar dari penelitian ini (motivation on buying souvenir, perceived value of souvenir, dan consumer behavior) yang tidak disebutkan peneliti berpengaruh terhadap jumlah permintaan souvenir di pasar seni Ubud.

\section{PEMBAHASAN}

Pengaruh Motivation on Buying Souvenir, Perceived Value of Souvenir, Consumer Behavior Terhadap Permintaan Souvenir di Pasar Seni Ubud Secara Parsial

Untuk hasil analisis regresi berganda, didapatkan bahwa secara parsial baik variabel motivation on buying souvenir $\left(\mathrm{X}_{1}\right)$ perceived quality of souvenir $\left(\mathrm{X}_{2}\right)$ dan variabel consumer behavior $\left(\mathrm{X}_{3}\right)$ telah terbukti berpengaruh positif dan signifikan terhadap jumlah permintaan souvenir di pasar seni Ubud (Y). Analisis tersebut telah memenuhi syarat penerimaan hipotesis, yaitu t-hitung yang memiliki nilai positif dan siginifikan yang lebih kecil dibandingkan nilai probabilitas. Sehingga hipotesis pertama, kedua dan ketiga dalam penelitian ini telah terbukti. Namun apabila dilihat dari ketiga variabel independen tersebut, variabel yang paling berpengaruh terhadap variabel dependen adalah variabel consumer behavior $\left(\mathrm{X}_{3}\right)$ karena variabel tersebut memiliki hasil t-hitung yang lebih besar dibandingkan hasil t-hitung pada variabel perceived quality $\left(\mathrm{X}_{2}\right)$ dan variabel motivation on buying souvenir $\left(\mathrm{X}_{3}\right)$. 
Indikator motivation on buying souvenir dalam penelitian ini meliputi; (1) souvenir as gift, dimana pembelian souvenir sebagai hadiah merupakan sebuah ritual yang sudah menjadi tradisi bagi wisatawan ketika mereka berkunjung ke suatu destinasi. (2) souvenir as memory, motivasi wisatawan atau pengunjung pasar seni Ubud dalam membeli souvenir sebagai memori merupakan sebuah pengalaman sesaat yang dapat diterima oleh wisatawan ketika mereka mengunjungi sebuah destinasi. Sehingga kenangan tersebut dapat mereka bawa hingga ke negara asal untuk menggambarkan atau mendorong ingatan seseorang akan sebuah peristiwa yang sudah lampau. (3) Souvenir as evidence merupakan motivasi pembelian souvenir dalam rangka perwujudan pengalaman yang nyata dari sebuah perjalanan. Hal tersebut merupakan bukti nyata bahwa mereka pernah melakukan perjalanan ke suatu destinasi sehingga ketika mereka kembali ke negara asal, souvenir tersebut merupakan perwujudan "tangible" dari sebuah peristiwa. Variabel tersebut dikembangkan kedalam 9 bentuk pernyataan. Variabel motivation on buying souvenir secara parsial memperoleh hasil thitung positif sebesar 18,955 dan siginifikan yang lebih kecil dibandingkan nilai probabilitas atau $0,000<0,05$. Hal tersebut menyatakan bahwa variabel tersebut secara positif dan signifikan berpengaruh terhadap permintaan souvenir di pasar seni Ubud Bali.

Indikator perceived value of souvenir dalam penelitian ini meliputi; (1) model atau design dari souvenir, dimana model atau design dianggap mewakili sifat atau ciri khas dari suatu destinasi. (2) Tradisional motif, atau ragam hias dari suatu barang sehingga souvenir akan memiliki nilai seni yang tinggi apabila motif yang dibentuk sesuai dengan seni klasik atau primitif khas daerah tersebut. (3) Kualitas souvenir, merupakan kondisi yang berkaitan dengan keseluruhan ciri atau atasa produk yang kegunaannya dapat memuaskan kebutuhan dari pembeli. Kualitas souvenir di pasar seni Ubud masuk kedalam kategori baik karena hampir keseluruhan souvenir tersebut merupakan kerajinan tangan masyarakat lokal di sekitar daerah Bali. Secara parsial variabel tersebut memperoleh hasil $\mathrm{t}$-hitung positif sebesar 3,525 dan siginifikan yang lebih kecil dibandingkan nilai probabilitas atau 0,001 $<0,05$. Hal tersebut menyatakan bahwa variabel tersebut secara parsial berpengaruh positif dan signifikan terhadap permintaan souvenir di pasar seni Ubud.

Indikator consumer behavior dalam penelitian ini meliputi; (1) lokasi pasar seni Ubud yang dianggap strategis oleh pengunjung karena berdekatan dengan beberapa objek wisata di central Ubud. Hal tersebut diakui oleh beberapa pengunjung pasar seni Ubud yang mayoritas merupakan wisatawan mancanegara. Mereka secara tidak sengaja berkunjung ke pasar Ubud karena pasar tersebut berdekatan dengan beberapa objek wisata seperti monkey forest, Puri Ubud, tegalalang, bukit campuhan dan lainnya. Selain itu lokasi dari pasar Ubud yang mudah diakses oleh wisatawan menambah minat wisatawan untuk berbelanja ke pasar seni Ubud. (2) Indikator kedua pada consumer behavior yaitu perlunya peningkatan kebersihan dari pasar seni Ubud. Mengingat kondisi pasar tradisional yang identik dengan keadaan kumuh, dan semrawut, sehingga dapat menambah keterpurukan kondisi pasar di era modern. Permasalahan tersebut dapat diatasai dengan kerjasama yang baik antara pedagang serta pengelola pihak pasar secara berkala sehingga eksistensi dari pasar seni tradisional di Bali dapat terjaga. (3) Indikator ketiga pada variabel consumer behavior yaitu pasar Ubud menawarkan harga yang terjangkau bagi mereka. Layaknya pasar tradisional, wisatawan dapat tawar menawar harga dengan pedagang sehingga harga didapat sangat terjangkau, hal ini sangat memungkinkan karena barangbarang kerajinan tangan incaran para turis di Pasar Ubud utamanya berasal dari desa-desa yang berada di sekitar Pasar Ubud itu sendiri, seperti Pengosekan, Tegallalang, Payangan dan Pelitan, desa-desa tersebut memang merupakan salah satu pusat kerajinan utama di Bali, sehingga sangat mungkin harga di Pasar Ubud akan lebih murah karena jarak sumber barang yang lebih dekat dibandingkan dengan berbelanja di tempat lainnya.

Selain itu wisatawan atau pengunjung berpendapat bahwa secara tidak langsung melalui kegiatan tawar menawar mereka dapat berkomunikasi dan mempelajari karakteristik atau budaya wisatawan, begitu sebaliknya. (4) Indikator tempat parkir yang perlu mendapatkan perhatian khusus atau pembenahan dari pihak pasar mengingat setahun silam pasar seni Ubud mengalami kebakaran dan menghanguskan sebagian pasar tersebut. Akibat dari musibah tersebut tentunya mempengaruhi lahan atau tempat berjualan 
para pedagang. Sehingga alternative yang bisa diberikan oleh pihak pengelola yaitu merelokasi para pedagang ke lahan parkir motor. (5) Indikator kelima yaitu infrastruktur dari pasar seni Ubud yang perlu ditingkatkan. Infrastruktur yang dimaksud seperti pembenahan gedung setelah adanya musibah kebakaran, sarana dan prasarana penunjang bagi pengunjung atau wisatawan di pasar. (6) Indikator lainnya dalam variabel consumer behavior yaitu jam operasional pasar seni Ubud, mengingat pasar tradisional pada umumnya hanya beroperasi pagi hingga sore. Hal ini berbeda dengan jam operasional yang ditawarkan oleh pasar modern. Namun beberapa pedangan di pasar tradisional mengakui bahwa jam operasional yang mereka terapkan saat ini sudah cukup membuat mereka kewalahan dalam melayani wisatawan atau pengunjung pasar, karena bahwasanya pedagang juga memiliki beberapa kegiatan atau upacara dan upakara adat yang harus mereka siapkan dan kerjakan. Berbeda halnya dengan pasar modern yang memiliki pegawa atau staff dan waktu kerja yang bergantian. Bila dilihat dari hasil t-hitung menunjukkan hasil positif yaitu 20,212 dan siginifikan yang lebih kecil dibandingkan nilai probabilitas atau 0,000 $<0,05$. Hal tersebut menandakan bahwa variabel consumer behavior berpengaruh positif dan signifikan terjadap permintaan souvenir di pasar seni Ubud.

Pengaruh Motivation on Buying Souvenir, Perceived Value of Souvenir, Consumer Behavior Terhadap Permintaan Souvenir di Pasar Seni Ubud Secara Simultan

Bila dilihat secara simultan, maka ketiga variabel independen (motivation on buying souvenir, perceived value of souvenir, dan consumer behavior) terbukti berpengaruh positif dan signifikan terhadap variabel dependen yaitu jumlah permintaan souvenir di pasar seni Ubud, hal tersebut terbukti dengan siginifikan yang lebih kecil dibandingkan nilai probabilitas atau $0,000<0,05$ dan nilai f-hitung positif $(419,961)$ sehingga telah memenuhi syarat penerimaan hipotesis, oleh karena itu hipotesis keempat dalam penelitian ini telah terjawab.

Hasil analisis determinasi menunjukkan bahwa variabel independen sebesar 90,9\% berpengaruh terhadap variabel dependen. Bila dikaitkan dalam penelitian Hugh Wilkins (2011), F. Vasheghani -Farahani (2014) dan
Nur Indah Purwanti (2012) mengenai motivasi, nilai dari souvenir dan pola perilaku konsumen telah terbukti jika dapat mempengaruhi jumlah permintaan souvenir di pasar Ubud sebesar $90,9 \%$, namun terdapat beberapa faktor lainnya sebesar $9,1 \%$ yang juga dapat mempengaruhi permintaan souvenir, atau bahkan variabel lainnya yang tidak diteliti dalam penelitian ini. Dalam penelitian $F$. Vasheghani -Farahani (2014) " Effective Factor on Souvenirs Purchase" terdapat empat variabel lainnya terkait teori "perceived value of souvenir " yaitu portable, price, local colours, application, yang juga berpengaruh. Sehingga bisa saja variabel-variabel yang tidak disebutkan peneliti berpengaruh terhadap jumlah permintaan souvenir di pasar seni Ubud.

\section{SIMPULAN DAN SARAN Simpulan}

Berdasarkan hasil penelitian yang telah dilakukan mengenai analisis permintaan souvenir di pasar seni Ubud, maka dapat disimpulkan bahwa secara parsial terdapat tiga variabel bebas yang memiliki pengaruh secara positif dan signifikan terhadap jumlah permintaan souvenir di pasar seni ubud yaitu (1) motivation on buying souvenir; as gift, as memory, and as evidence dengan pegaruh sebesar 18,955 (2) perceived value of souvenir dengan pengaruh sebesar 3,525 (3) consumer behavior dengan pengaruh sebesar 20,212 dan keseluruhan nilai siginifikan yang lebih kecil dibandingkan nilai probabilitas. Pada hasil consumer behavior yang terdiri dari lokasi pasar, kebersihan pasar, harga, tempat parkir, infrastruktur dan jam operasional pasar yang paling berpengaruh positif dan signifikan terhadap jumlah permintaan souvenir di pasar seni Ubud.

Secara simultan, variabel bebas yang terdiri dari motivation on buying souvenir, perceived value of souvenir, dan consumer behavior dari hasil uji signifikan regresi berganda berpengaruh positif dan signifikan terhadap variabel terikat yaitu permintaan souvenir (Y) di pasar seni Ubud Bali dengan nilai 419,961 dan siginifikan yang lebih kecil dibandingkan nilai probabilitas atau 0,000 $<0,05$.

Dari hasil perhitungan koefisien determinasi memiliki nilai $\mathrm{R}$ square $90,9 \%$ sehingga menunjukkan bahwa variabel bebas yang meliputi motivation on buying souvenir $\left(\mathrm{X}_{1}\right)$ perceived value of souvenir $\left(\mathrm{X}_{2}\right)$ dan 
consumer behavior $\left(\mathrm{X}_{3}\right)$ terhadap permintaan souvenir (Y) sebesar 90,0\%. Sehingga terdapat 9,1\% variable lainnya yang dapat berpengaruh terhadap permintaan souvenir yang lain diluar dari penelitian ini (motivation on buying souvenir, perceived value of souvenir, dan consumer behavior).

\section{Saran}

Berdasarkan hasil penelitian dan pembahasan diatas maka dapat dikemukakan saran kepada pihak pengelola pasar dan juga akademisi bahwa beberapa solusi sebaiknya dipertimbangkan oleh pengelola pasar tradisional sehingga konsumen tidak merasa enggan berbelanja souvenir di pasar tradisional. Solusi tersebut antara lain perbaikan atau peningkatan sarana dan prasarana penunjang bagi pengunjung pasar. Selain itu perlu adanya perbaikan infrastruktur bangunan pasar tradisional setelah adanya musibah kebakaran yang berakibat pada mengurangnya lahan parkir dan semakin sempitnya ruang gerak pengunjung dan pedagang di pasar Ubud. Kondisi pasar yang sudah relatif tua, terkesan kumuh, semrawut dan banyak bagian bangunan yang sudah rusak akan memberikan kesan yang tidak nyaman bagi pengunjung.

Selain pengelola pasar, beberapa saran diatas juga perlu dipertimbangkan bagi pedagang lokal. Seperti mengadakan kebersihan massal tiap minggunya atau secara bersamaan menjaga kebersihan pasar demi terciptanya kenyamanan bersama. Menjaga sikap keramah tamahan kepada pembeli juga dapat meningkatkan penghasilan karena selain faktor harga, wisatawan atau pengunjung memilih untuk berbelanja di pasar seni karena rasa penasaran akan social life dan cara berkomunikasi dari pedagang lokal.

Perlu adanya penelitian lebih lanjut mengenai faktor-faktor lain yang berpengaruh terhadap jumlah permintaan souvenir di pasar seni Ubud Bali selain variabel motivasi, karakteristik, pola perilaku dan nilai dari souvenir. Karena seperti yang telah dijelaskan sebelumnya bahwa masih ada $9,1 \%$ variabel lainnya yang belum dijelaskan dalam penelitian ini. 


\section{Kepustakaan}

Federico, Giovanni. 2006. Market Integration and Market Efficiency:The Case of 19th Century Italy"Departement of History and Civillization, European University institute.

Gordon, Beverly. "The souvenir: Messenger of the extraordinary." The Journal of Popular Culture 20.3 (1986): 135146.

Kim, Soyoung, and M A Littrell. 2001. Souvenir buying intentions for self versus others. Annals of Tourism Research 28 (3):638-657.

Peter,Olson. 2005. Consumer Behaviour and Marketing Strategy. New York: Mc. Graw Hill.

Putra, I Gede Cahyadi (et al), 2012,: Faktor Internal Dan Eksternal Yang Berpengaruh Pada Pendapatan Pedagang Pasar Seni Sukawati Setelah Berkembangnya Pasar Oleh-Oleh Modern Di Kabupaten Gianyar" pp 1-11.

Sugiyono..2015. Metode Penelitian Pendidikan (Pendekatan Kuantitatif, Kualitatif dan $R \& D)$. Penerbit CV. Alfabeta: Bandung. 